\title{
Translation Strategies in Legal Texts: Selected Articles of the Translation of the US-Iraqi Security Agreement
}

\author{
Ahmed I. Abed ${ }^{1}$, Omar A. Shihab ${ }^{2}$ and Mushtaq A. Jameel ${ }^{3}$ \\ ${ }^{1}$ Department of English, College of Arts, Imam Ja'afar Alsadiq University, Salah-Aldin, Iraq \\ ${ }^{2}$ Department of Translation, College of Arts, Tikrit University, Tikrit, Iraq \\ ${ }^{3}$ Department of Archeology, College of Archeology, University of Mosul, Mosul, Iraq
}

\begin{abstract}
Legal language is characterized as the professional use of words. Thus, it can be said that the international law (as a result of translation and interpretation as well) has become more crucial. Therefore, legal translation has become important among the other domains of translation. This study aims at investigating the translation strategies adopted in translating the US- Iraqi security agreement from English into Arabic. So, there is a set of translation strategies that help translating the two texts properly and accurately. The translation strategies followed in translating the US- Iraqi security agreement will be investigated in the two of the two English and Arabic texts as there are many strategies in the linguistic theory of translation. Dr. As. Safi in his model covers both the local strategies which belonging to text segment and global ones that have to do with the whole text. Translation strategies are divided into general ones which deal with all types texts and specific strategies that deal with specific kinds of texts; specific ones are divided into domestication, compensation, (in kind, in place, by merging, or splitting and compensation by addition) , addition, elaboration and explication, and approximation and compromise. Thus, the text under study is a legal one and, of course, has a specific type of text; only specific strategies are applied in this study.
\end{abstract}

Index Terms - FL, Legal translation, SL Translation strategies, Theories of translation, US-Iraqi Security Agreement.

\section{INTRODUCTION}

In 2010, the USA and Iraq agreed to end the American military presence in Iraq. For this purpose, two versions of an agreement, i.e. English and Arabic were simultaneously signed by the two parties. This agreement is publically called the "security" (or withdrawal) agreement. Due to the precautions of the two parties of any possible future violation, the two versions of the agreement appeared after a long time of negotiations and a great effort of work on all its segments to have agreed-upon legal text formulation precisely written or translated into English as well as Arabic, so as to give the intentions of the texts.

On the translation level, it is obvious that the items of this legal text had undergone various trials of translation from English into Arabic and/or vice versa in order to put them in their ultimate form. As such, there seems to be no full original agreement form (i.e. text) written first in one language to be translated later into another as it is the case with some other international agreements. On the textual level, this could consequently imply that for readers and analyzers, anyone of the two whole text versions of this agreement can neither be considered as a source text (ST) nor even as a target text (TT). Still, there is certainly a translation process of a legal text from one language into another. No doubt, translators have tried various techniques, procedures and strategies. This paper is conducted to find out the translation strategies adopted in translating, from English into Arabic and vice versa, the USIraqi security agreement (for full text of the agreement see: (http://arabic.iraq.usembassy.gov/american -iraqi.html).

The language of law or the legal language has commonly been portrayed as the skillful use of words, or as David Crystal expressed "The professional" use of words (1987, P. 387). Written legal texts are usually featured as being produced with long sentences, complex structures, repetition, more of Latinism and old or archaic lexis (Bhatia, 1993). This complex use of the language in the legal "register" or "genre" gave rise in the last decades to a tendency or claims for making laws and legislations more understandable by the professionals as well as the public with the use of "plain" language.

Translation process of any text, not only legal, requires understanding two texts. The source text (ST) and the target text (TT), and the translator's job is to find an "equivalence" relation between the both in order to change the first in one language into the second in another language.

Journal of University of Human Development

Volume 5 No. 3(2019); DOI: 10.21928/juhd.v5n3y2019.pp134-141

Regular research paper: Published 29 July 2019

Corresponding author's e-mail: ahibrahim60@gmail.com,Oshihab6@gamil.com, Majameel82@gmail.com

Copyright () 2019 Ahmed I. Abed Omar A. Shihab, Mushtaq A. Jameel. This is an open access article distributed under the Creative Commons Attribution License (CC BY-NC-ND 4.0) 


\section{THEORIES OF TRANSLATION}

The existence of many languages has made the process of translation obligatory. For two thousand years, translation has been concerned with outstanding works of art. As soon as two speakers of different languages need to converse, translation is necessary. Since translation involves languages, the analysis and the description of translation process shall be drawn up on a theory of translation. Later trends in linguistics have laid emphasis on the need to set up a theory of translating that has different methods which the translator might use to arrive at a precise and more accurate work of translation (Shaheen, 1991, p. 2).

Translation theory is derived from comparative linguistics. Kelly (1979, p. 34) mentions that 'to each stream of language theory, there corresponds a theory of translation'. The founder of translation theory is the American philosopher C.S. Peirce. However, he stresses the importance of communicative aspect of meaning in that it includes all the effects that surround the linguistic factor. Therefore, "translation theory's main concern is to determine appropriate translation methods for the widest possible range of texts or text-categories. Further, it provides a frame work of principles, restricted rules and hints for translating texts and criticizing translations, a background for problem-solving" (Newmark, 1981, p. 19)

Catford (1965, p. 20) states that "the theory of translation is concerned with a certain type of relation between languages and is consequently a branch of Comparative Linguistics'. Thus translating can be defined as 'the replacement of textual material in one language (SL) by equivalent textual material in another language TL.' With this in mind, Catford distinguishes between different types of translation equivalence, i.e. textual equivalence and formal correspondence.

Moreover, translation theory is composed of three periods: the first period starts with Roman. Thus, Jacobson considers translation as Roman invention. Then, this period includes Horace and Ciecero where they make important distinction between word-for-word and sense-for-sense translation. This, as a result, leads to the aesthetic criteria of the TL product. Horace warns of overcautious imitation of the source language. However, this period is best described by Tytler. He mentions three laws:(1) the translation should give a complete ideas to the ones with the original, (2) the style and manner of writing should be the same, (3) translation should include all the ease of the original (Bell, 1991, p. 11)

The second period occurs in the twentieth century and it is characterized as a theory of developing vocabulary and methodology of approaching translation. Hence, Etienne Dolet is one of the theorists of this period then he establishes five principles for the translator: (1) the translator must fully understand the sense and the meaning of the original text, (2) the translator should have a perfect knowledge in both SL and TL, (3) he should avoid word-for-word translation, (4) he should use speech of common use,.

Dolet stresses the importance of understandability of the original text as a primary task. Moreover, George Chapman explains Dolet's principles and asserts that "the work of a skillful and worthy translator is to observe the sentences, figures and forms of speech" (Bassnett, 1988, p. 58). He repeats the theory by mentioning that: (1) avoid word-for-word, (2) attempt to reach the 'spirit' of the original and (3) avoid over loose translations.

John Dryden (1631-1700) (cited in As- Safi, 2001, p. 242) tackles the problem of translation by formulating three basic types: (1) metaphrase: word-for-word and line by line, (2) paraphrase: sense-for-sense translation, and (3) imitation: the translator can leave the text of the original as he sees fit. The third period is the shortest and it extends to less than three decades with the publication of the of the first papers on machine translation in 1940s and is featured by the introduction of structural and applied linguistics, contrastive studies in morphology and syntax which helps the translator identifying similarities and differences between NL and FL and communication theory into the study of translation.

Nida (1976, p. 19) states "that due to the fact that translation is an activity involving language there is a sense which any and all theories of translation are linguistic. He divided these theories into three branches: philological theories, linguistic theories and socio-linguistic theories. Philological theories of translation depend on "philology" which is concerned with the development of language. They have to do with comparing the structures of native and foreign language. As for linguistic theories, they are concerned with the comparison of linguistic structures between the ST and TT, instead of comparing literary genres of features of style. According to Nida and Taber (1969, p. 134), it is only a linguistic translation that can be considered 'faithful', because it "is one which only contains elements which can be directly derived from the ST wording, avoiding any kind of explanatory interpolation or cultural adjustment which c a n be justified on this basis."

With reference to linguistic theories, Newmark's classification of translation into semantic and communicative, which somehow represents Nida's formal and dynamic equivalence. Communicative translation, as Newmark (1981, p. 39) states, attempts to produce on its readers an effect as close as possible to that obtained on the original. On the other hand, Semantic translation attempts to render, as closely as the semantic and syntactic structures of the second language, the exact contextual meaning of the original (Newmark, 1981, p. 39). The last taxonomy of Nida's classifications is Sociolinguistic Theories. These theories require linking translation to communicative theory in that the translator needs to have a knowledge in both competence and performance, the translator, according to this theory, should use rhetorical devices or figures of speech such as simile, metaphor, irony in both literary and non-literary texts.

\section{TRANSLATION STRATEGIES}

Jaaskelainen (1999, p. 71) considers strategy as "a series of competencies, a set of steps or processes that favor the acquisition, storage, and/or utilization of information. He maintains that strategies are "heuristic and flexible in nature, and their adoption implies a decision influenced by amendments in the translator's objectives." Moreover, Loescher 
(1991, p. 8) defines translation strategy as "a potentially conscious procedure for solving a problem faced in translating a text. Baker (2005, p. 188) mentions that "a translation strategy is a procedure for solving a problem encountered in translating a text or a segment of it. Therefore, strategies can be classified between local ones which deal with text parts and global strategies that deal with the whole texts. Both local and global strategies have to do with relevant elements of the translator's background knowledge: critical awareness of the style and content of similar texts, of linguistic conventions, register and intuitions about what constitutes the target language (ibid).

Translation strategies can be categorized into general and specific strategies. General strategies, on the one hand, deal with all types of texts. On the other hand, specific strategies deal with certain text type. Regarding these strategies, they are of five sub-types:-

\section{A. Domestication Strategy}

This strategy is also called normalization. It is employed to fill the cultural gabs which and achieve sufficiency that focuses on interpretation and give the translator the right to elaborate the text so as to make it readable, comprehensible, and natural. This strategy is also adopted by literary translators to show the cultural values of TT (As- Safi, 2011, p. 54).

\section{B. Compensation Strategy}

Compensation is, according to Sandor Hervey and Ian Higgins (1992, p. 248), "the technique of making up for the translation loss of significant features of the source text (henceforth ST) approximating their effects in the target text (henceforth TT) through means other than those used in the ST, that is making up for the ST effects achieved by one means through using another means in the TL". This strategy can be divided into four sub-strategies (ibid)

\section{1) Compensation in Kind}

This strategy refers to the compensation of a particular kind of a textual effect which is understandable into the TT by using textual effect of a different type in the TT. An example is the Arabic emphatic LAM and NOON as linabluwnnakum ((Surely We will try you), compensated by lexical items such as truly, verily, surely.. etc., as in the Qur'anic aya 155 of surat AlBaqara (the Cow) (ibid).

\section{2) Compensation in Place}

This refers to the compensation of a loss in a particular textual effect occurring in a certain place in the ST, by making a kind of effect at a given place in the TT (ibid).

\section{3) Compensation by Merging}

This strategy has to do with carrying over a long stretch of the ST into a shorter stretch of the TT, as in translating (التضحية (و الفداء into (sacrifice) (As Safi, 2011, p. 54).

\section{4) Compensation by Splitting}

This feature is distributed with a shorter stretch in the ST by a longer stretch in the TT, as in the example is the translation of the "Islamic term (al-Ihraam الاحرام) into English as "a state in which one is prohibited to exercise certain deeds and practices that are religiously permitted at another state or circumstance."

\section{5) Compensation by Addition}

This is the aspect of compensating the loss in the translation by adding some fields such as an idiom, metaphor, etc. that has no counterpart in the TT.

\section{Strategy of Addition}

This refers to the aspect of adding certain lexical item or an effect to the TT.

\section{Strategy of Elaboration and Explication}

To convey the message as that implied in the ST, the translator resorts to Elaboration or Explication. Here is again an example from Shakespeare's The Merchant of Venice: Shylock:

ما اخبار ريالتو (ما اخبار البورصة)? (As-Safi, 2011, pp. 58-59)

\section{E. Strategy of Approximation and Compromise:}

This strategy requires the balance between the SL aesthetic and cultural values which are acceptable or unacceptable in the TL. We follow this strategy among others, in translating Taha Hussein's Dua'a Al-Karawan (the Call of the Curlew) into English,

The dilemma facing the present translator is how to bring about an equilibrium whereby the original aesthetic flavor is transferred into English without hindering genuine comprehension or producing something that can be rejected as totally "UN English". In many cases, only an approximation, rather than complete translation, is possible in order to present a natural, acceptable rendition. (As-Safi, 1980 cited in (As-Safi, 2011, p. 59).

\section{DATA ANALYSIS}

In this paper, seven articles of the US-Iraqi security agreement will be investigated depending on the strategies that are used in translating these articles. Since the legal texts are special register and require special translations; however, this study adopts As-Safi's strategies, which cover both general and specific ones. General strategies, on the one hand, deal with all types of texts. On the other hand, specific strategies deal with certain text type. The analysis includes mentioning the articles in the English and Arabic pattern, then discussing the way they are translated.

\section{1) $\mathrm{ST}$}

\section{Article 2}

Definition of Terms

"Agreed facilities and areas" are those Iraqi facilities and areas owned by the Government of Iraq that are in use by the United States Forces during the period in which this Agreement is in force.

\section{TT}

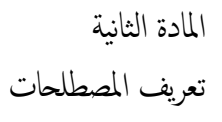




$$
\begin{aligned}
& \text { المنشاءات و المساحات المتفق عليها هي المنشاءات و المساحات التي تملكها حكومة }
\end{aligned}
$$

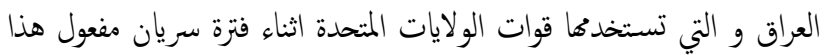

$$
\begin{aligned}
& \text { الاتفاق }
\end{aligned}
$$

Discussion:

It can be pointed out that this article is translated depending strategies of translation. The first strategy is Domestication in which the translator manipulates the text to be as the original. The translator is making a balance between the ST and TT. Moreover, he tries to convey the message deemed to the Arabic style. The second strategy is compensation by splitting in that the word in force is conveyed to TT with a long stretch in the TT to give the same effect.

Table (1)

Analysis of the translation Strategies

\begin{tabular}{|l|l|l|}
\hline \multirow{4}{*}{ ST } & Translation Strategies & \\
\cline { 2 - 3 } & Domestication & + \\
\hline & Compensation & \\
\cline { 2 - 3 } & Compensation in kind & \\
\cline { 2 - 3 } & Compensation in place & \\
\hline & Compensation by splitting & + \\
\hline & Compensation by merging & \\
\cline { 2 - 3 } & Compensation by addition & \\
\cline { 2 - 3 } & Addition & \\
\cline { 2 - 3 } & Elaboration and Explication & \\
\hline
\end{tabular}

2) ST

Article 3

Laws

1. While conducting military operations pursuant to this Agreement, it is the duty of members of the United States Forces and of the civilian component to respect Iraqi laws, customs, traditions, and conventions and to refrain from any activities that are inconsistent with the letter and spirit of this agreement. It is the duty of the United States to take all necessary measures for this purpose.

2. With the exception of members of the United States Forces and of the civilian component, the United States Forces may not transfer any person into or out of Iraq on vehicles, vessels, or aircraft covered by this agreement, unless in accordance with applicable Iraqi laws and regulations, Including implementing arrangements as may be agreed to by the government of Iraq.

TT

$$
\begin{aligned}
& \text { المادة الثالثة } \\
& \text { القوانين } \\
& \text { 1. تلتزم افراد قوات الولايات المتحدة و العنصر المدني بواجب احتزام القوانين و الماني }
\end{aligned}
$$

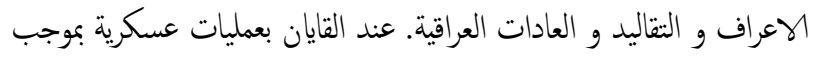

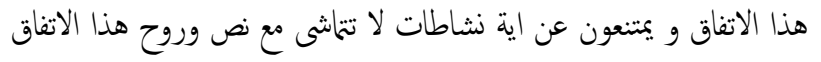

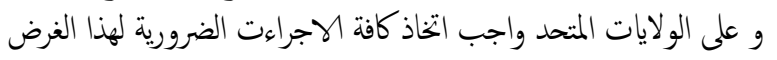

$$
\begin{aligned}
& \text { 2. باستثناء افراد الولايات المتحدة و افراد العنصر المدني لايجوز لقوات الولايات }
\end{aligned}
$$

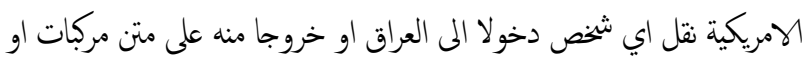

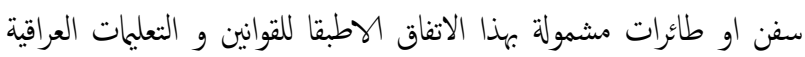

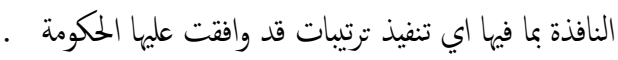

Discussion:

1. Here, domestication is used to convey the message so as to be comprehensible and readable in the TT. Moreover, elaboration and approximation is also used to approximate the original text in terms of structure.

2. Depending on strategies, the word letter is translated into (نص) according compensation in place. Additionally, the strategy of compensation is also used to provide loss of features in the TT and to give the same effect as the one in ST.

3. The second part of this article is translated using the strategy of addition and compensation. The translator renders the term (into and out) into Arabic using the strategy of compensation by splitting in which a shorter term is rendered into (دخو لا الى العراق او خروجا منه ) whereas the rest part is translated using the strategy of elaboration and explication to make a kind of balance between both translations.

Table (2)

Analysis of the translation Strategies

\begin{tabular}{|l|l|l|}
\hline ST & Translation Strategies & features \\
\cline { 2 - 3 } & Domestication & + \\
\cline { 2 - 3 } & Compensation & \\
\cline { 2 - 3 } & Compensation in kind & \\
\cline { 2 - 3 } & Compensation by splitting & + \\
\cline { 2 - 3 } & Compensation in place & + \\
\cline { 2 - 3 } & Compensation by merging & \\
\cline { 2 - 3 } & Compensation by addition & \\
\cline { 2 - 3 } & Addition & \\
\cline { 2 - 3 } & Elaboration and Explication & + \\
\hline
\end{tabular}

\section{3) $\mathbf{S} \mathbf{T}$}

Article 6

Use of Agreed Facilities and Areas

1. With full respect for the sovereignty of Iraq, and as part of exchanging views between the Parties pursuant to this Agreement, Iraq grants access and use of agreed facilities and areas to the United States Forces, United States contractors, United States contractor employees, and other individuals or entities as agreed upon by the Parties.

$$
\begin{aligned}
& \text { TT } \\
& \text { المادة السادسة } \\
& \text { استخدام المنشاءات و المساحات المتفق عليها }
\end{aligned}
$$

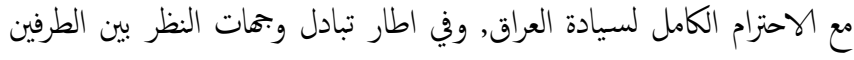

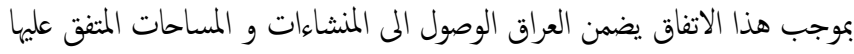

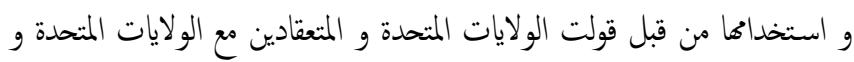




$$
\text { المرفتخدمين العاميلين لدى هؤلاء المتعاقدين و الافراد و الكيانات حيثا يتفق عليها }
$$

Discussion:

In this article, elaboration and explication is conducted to transfer the required meaning to the TT to approximate the implied meaning between the ST and TT. Moreover, the strategy of addition is also utilized where the word (parties) is translated into (الطرفين) to give the same textual effect implied in this word.

Table (3)

Analysis of the translation Strategies

\begin{tabular}{|l|l|l|}
\hline \multirow{4}{*}{ ST } & Translation Strategies & Features \\
\cline { 2 - 3 } & Domestication & \\
\cline { 2 - 3 } & Compensation & \\
\cline { 2 - 3 } & Compensation in kind & \\
\cline { 2 - 3 } & Compensation in place & \\
\cline { 2 - 3 } & Compensation by splitting & \\
\cline { 2 - 3 } & Compensation by merging & \\
\cline { 2 - 3 } & Compensation by addition & \\
\cline { 2 - 3 } & Addition & + \\
\hline & Elaboration and Explication & + \\
\hline
\end{tabular}

\section{4) $\mathrm{ST}$}

Article 13

Carrying Weapons and Apparel

Members of the United States Forces and of the civilian component may possess and carry weapons that are owned by the United States while in Iraq according to the authority granted to them under orders and according to their requirements and duties. Members of the United States Forces may also wear uniforms during duty in Iraq.

\section{TT}

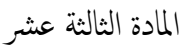

$$
\begin{aligned}
& \text { حمل الاسلحة و البزات العسكرية }
\end{aligned}
$$

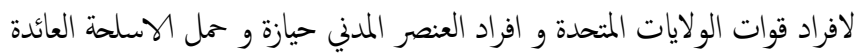

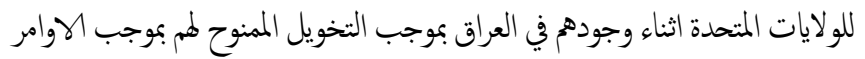

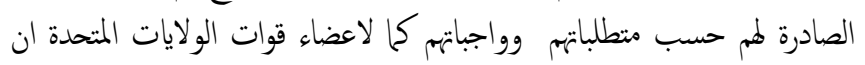

$$
\begin{aligned}
& \text { يرتدو البزات العسكرية اثناء تادية واجباتهم في العراق . }
\end{aligned}
$$

Discussion:

In this article, approximation is utilized to translate the modal verb (shall) used in the ST to the Arabic letter (J) as kind of obligation to approximate the original text. Moreover, compensation in place is also used to translate the word (while in) into (بينهما في) to cope with original text. Furthermore, compensation by splitting is used to convey (uniforms) into

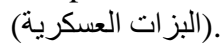

Table (4)

Analysis of the translation Strategies

\begin{tabular}{|l|l|l|}
\hline \multirow{4}{*}{ ST } & Translation Strategies & Features \\
\cline { 2 - 3 } & Domestication & \\
\cline { 2 - 3 } & Compensation & \\
\cline { 2 - 3 } & Compensation in kind & \\
\cline { 2 - 3 } & Compensation in place & \\
\cline { 2 - 3 } & Compensation by splitting & \\
\cline { 2 - 3 } & Compensation by merging & \\
\cline { 2 - 3 } & Compensation by addition & \\
\cline { 2 - 3 } & Addition & + \\
\cline { 2 - 3 } & Elaboration and Explication & + \\
\hline
\end{tabular}

\section{5) $\mathbf{S ~ T}$}

Article 24

Withdrawal of the United States Forces from Iraq

1. Recognizing the performance and increasing capacity of the Iraqi Security Forces, the assumption of full security responsibility by those Forces, and based upon the strong relationship between the Parties, an agreement on the following has been reached: all the United States Forces shall withdraw from all Iraqi territory no later than December 31, 2011.

2. All United States combat forces shall withdraw from Iraqi cities, villages, and localities no later than the time at which Iraqi Security Forces assume full responsibility for security in an Iraqi province, provided that such withdrawal is completed no later than June 30, 2009.

3. United States combat forces withdrawn pursuant to paragraph 2 above shall be stationed in the agreed facilities and areas outside cities, villages, and localities to be designated by the JMOCC before the date established in paragraph 2 above.

4. The United States recognizes the sovereign right of the Government of Iraq to request the departure of the United States Forces from Iraq at any time The Government of Iraq recognizes the sovereign right of the United States to withdraw the United States Forces from Iraq at any time.

5. The Parties agree to establish mechanisms and arrangements to reduce the number of the United States Forces during the periods of time that have been determined, and they shall agree on the locations where the United States Forces will be present.

T L

$$
\text { السحاب القوات الامريكة والعشرونة من العراق }
$$

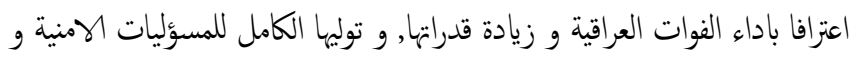

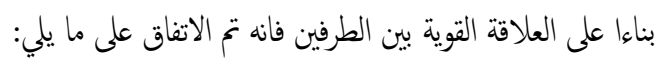

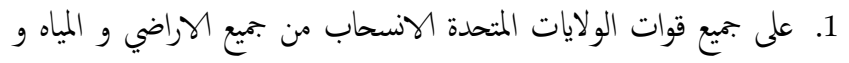

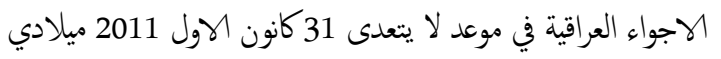

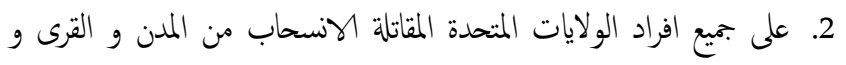

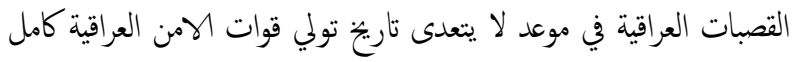




$$
2009 \text { الولايات المتحدة من المنية عن الامن في اية محافطة عراقية , على ان يكتمل انسحاب قوات المذكورة اعلاه في موعد لا يتعدى } 30 \text { حزيران }
$$$$
\text { 3. تتمركز قوات الولايات المتحدة المنسحبة عملا بالفقرة (2) اعلاه في المنشاءات }
$$

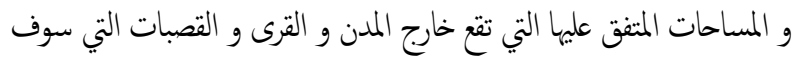$$
\text { تتحددها اللجنه المشتركة لتنسيق العمليات العسكرية قبل التاريخ المحدد في التي }
$$$$
\text { الفقرة } 2 \text { اعلاه }
$$

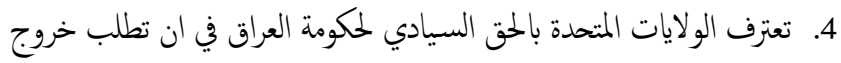

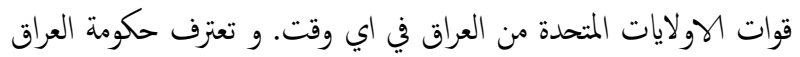

$$
\text { بالجت السيادي للولايات المتحدة من العراق في اي وقت مضى المئ. }
$$

Discussion:

1. In this article, domestication is utilized to grant the translator conveying the message or make a kind of adoption to the ST text to give the same effect. In addition, the obligatory particle (shall) is approximated into ( يجوز, (على , to be coincided with original norms.

2. Compensation by merging is used to translate (no later than) in which a long stretch of words is translated in TT into (لا يتعدى).

3. Addition is also utilized where (من الاماكن المذكورة اعلاه) are added to the TT to make it more comprehensible.

Table (5)

Analysis of the translation Strategies

\begin{tabular}{|l|l|l|}
\hline \multirow{4}{*}{ SL } & Translation Strategies & Features \\
\cline { 2 - 3 } & Domestication & + \\
\hline & Compensation & \\
\cline { 2 - 3 } & Compensation in kind & \\
\cline { 2 - 3 } & Compensation in place & \\
\cline { 2 - 3 } & Compensation by splitting & \\
\hline & Compensation by merging & + \\
\hline & Compensation by addition & \\
\hline & Addition & + \\
\hline & Elaboration and Explication & + \\
\hline
\end{tabular}

\section{6) $\mathrm{S} T$}

\section{Article 25}

Measures to Terminate the Application of Chapter VII to Iraq

Acknowledging the right of the Government of Iraq not to request renewal of the Chapter VII authorization for and mandate of the multinational forces contained in United Nations Security Council Resolution 1790 (2007) that ends on December 31, 2008;

Taking note of the letters to the UN Security Council from the Prime Minister of Iraq and the Secretary of State of the United States dated December 7 and December 10, 2007, respectively, which are annexed to Resolution 1790,

Taking note of section 3 of the Declaration of Principles for a Long-Term.

Relationship of Cooperation and Friendship, signed by the President of the United States and the Prime Minister of Iraq on
November 26, 2007, which memorialized Iraq's call for extension of the above-mentioned mandate for a final period, to end not later than December 31, 2008 :

Recognizing also the dramatic and positive developments in Iraq, and noting that the situation in Iraq is fundamentally different than that which existed when the UN Security Council adopted Resolution 661 in 1990, and in particular that the threat to international peace and security posed by the Government of Iraq no longer exists, the Parties affirm in this regard that with the termination on December 31, 2008 of the Chapter VII mandate and authorization for the multinational force contained in Resolution 1790, Iraq should return to the legal and international standing that it enjoyed prior to the adoption of UN Security Council Resolution 661 (1990), and that the United States shall use its best efforts to help Iraq take the steps necessary to achieve this by December 31, 2008.

\section{TT}

$$
\text { المادة الخامسة و العشرون }
$$

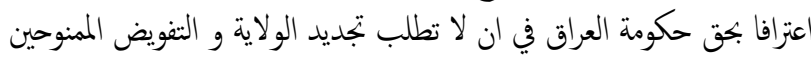

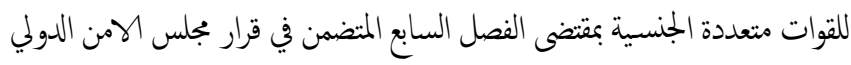
رقز (1790) (2007) و هو النفويض الذي ينتهي صلاحيته يوم 31 كانون الاول عام 2008

و توبها بالرسالتين الموجهتين الى مجلس الامن الدولي: رسالة من رئيس الوزراء العراق و رسالة من وزير الخارجية في الولايات المتحدة الامريكية بتاريخ 7 و و 10 كانون الهول 2007 على التوالي و هـا ملحقتان بالقرار 1790

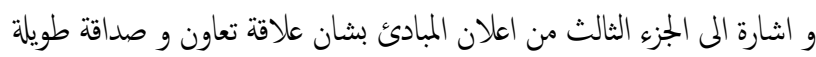

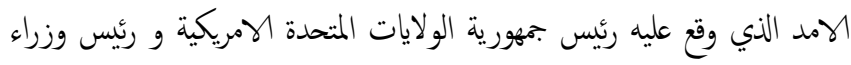
العراق يوم 26 تشرين الثاني 2007 و الذي سبل للنّل التاريخ دعوة العراق المى مد فترة التفويض المشار اليه لفتره اخيره تنهي في تاريخ لا يتعدى 31 كانون الاول 2008 ,

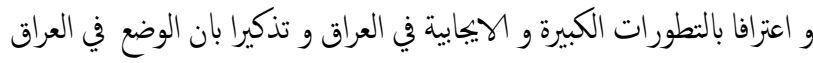
يختلف اختلافا اساسيا عن الوضع الذي كان قائما عندما تبنى مجلس الامن الدولي

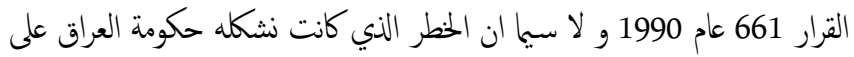
السلام و الهن الدوليين قد زال: فان الطرفين يؤكدان في هذا الصدد انه مع انهاء العمل يوم 31 كانون الاول 2008 بالولاية و التفويض الممنوحين للقوات متعددة الجنسية بمقتضى الفصل السابع المتضمن قرار مجلس الامن الدولي رقة 1790 ينبني ان يسترد العراق مكانته القانونية و الدولية التي كات بتمتع بها قب تبني قرار مجلس

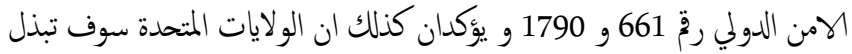
افضل جهودها لمساعدة العراق على اتخاذ الخطوات اللازمة لتحقيق ذلك بحلول ئول يور 2008 كانون الهول كودهمل

Discussion:

In this article, the first strategy that is used for translating is domestication. Hence, many cultural-legal specific words are translated utilizing this strategy. In addition, compensation by splitting translating the word (authorization into (الولاية (والتفويض()). The other strategy is addition where the words 
(taking note of the letters) is translated into (تنويها بالرسالتين)) where the number of the letters is not mentioned in the ST then is added to the TT. Moreover, the strategy of elaboration and explication is used to convey the message implied in the ST by translating the TT with the balanced effect that are found in the ST.

Table (6)

Analysis of the translation Strategies

\begin{tabular}{|l|l|l|}
\hline ST & Translation Strategies & Features \\
\cline { 2 - 3 } & Domestication & + \\
\cline { 2 - 3 } & Compensation & \\
\cline { 2 - 3 } & Compensation in kind & \\
\cline { 2 - 3 } & Compensation by splitting & + \\
\cline { 2 - 3 } & Compensation by merging & \\
\cline { 2 - 3 } & Compensation by addition & \\
\cline { 2 - 3 } & Addition & + \\
\cline { 2 - 3 } & Elaboration and Explication & + \\
\hline
\end{tabular}

7) $\mathrm{S} T$

Article 30

The Period for which the Agreement is Effective

1. This Agreement shall be effective for a period of three years, unless terminated sooner by either Party pursuant to paragraph 3 of this Article.

2. This Agreement shall be amended only with the official agreement of the Parties in writing and in accordance with the constitutional procedures in effect in both countries.

3. This Agreement shall terminate one year after a Party provides written notification to the other Party to that effect.

4. This Agreement shall enter into force on January 1, 2009, following an exchange of diplomatic notes confirming that the actions by the Parties necessary to bring the Agreement into force in accordance with each Party's respective constitutional procedures have been TT completed.

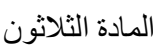

مدة سريان مفعول هذه الاتفاقية

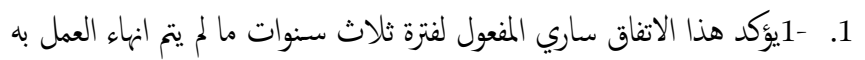

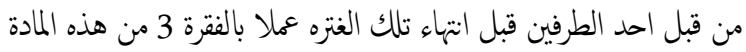

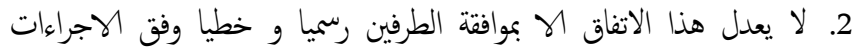

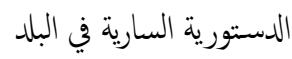

3. ينهي المل بهذا الاتفاق بعد مرور سنة واحدة من استلام احد الطرفين من الطن

الطرف الاخر اخطارا خطيا بذلك الك الكن

4. يدخل هذا الاتفاق حيز التنفيذ اعتبارا من اليوم الاول من كانون الثاني 2009

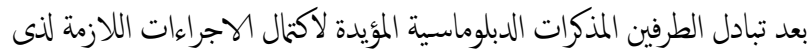

كل منها لتنفيذ الاتفاق وفقا للاجراءات الدستورية النافذة لدى الطرفين.

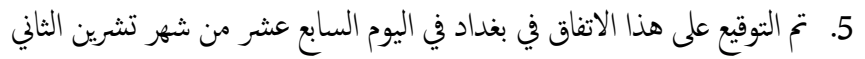

2008 بنسختين باللغة العربية و الانجليزية و يتساوى النصان في الحجة التهن القانونية.
Discussion:

In this article, domestication is elaborated to convey the lexical word (shall) into (يكون) since it is a legal system. Moreover, the title is translated depending on compensation by slitting in which the word (effective) is rendered into ( مدة سريان (مفعول) i.e. a short stretch in the ST is rendered into a long stretch in the TT. Moreover, in the second, third point is translated using Elaboration and Explication to convey the message implied in the ST to the TT. Additionally, the word (to that effect) is rendered with compensation in kind to give the loss of textual effect occurring in the ST when translating to the TT. Moreover, the word (into force) is rendered as (حيز التنفيذ) and the (bring the agreement into force) is translated using compensation by merging. Elaboration and Explication is also used to balance the two English and Arabic texts since both of these two texts require specific use of words that are applicable to the legal language.

Table (7)

Analysis of Translation Strategies

\begin{tabular}{|l|l|l|}
\hline \multirow{4}{*}{ ST } & Translation Strategies & Features \\
\cline { 2 - 3 } & Domestication & + \\
\cline { 2 - 3 } & Compensation & \\
\cline { 2 - 3 } & Compensation in kind & + \\
\cline { 2 - 3 } & Compensation by splitting & + \\
\cline { 2 - 3 } & Compensation by merging & \\
\cline { 2 - 3 } & Compensation by addition & \\
\cline { 2 - 3 } & Addition & + \\
\cline { 2 - 3 } & Elaboration and Explication & \\
\hline
\end{tabular}

\section{FINDINGS}

This research paper, so far, has discussed translating legal texts. Hence, seven articles from both English and Arabic texts are studied according to strategies by which these articles are translated. The purpose of this paper is to show how these articles are translated utilizing the eight strategies adopted by As Safi.

The analysis of data and tables have brought to light some important findings:-

1. In legal translation, domestication is mostly used to transfer the meaning of the TT due to the specific legal text. Thus, it is the right strategy to translate these kind of texts.

2. Addition is also used to add certain expressions to support the meaning in terms of the metaphorical features to make a kind of balance.

3. Compensation by splitting, merging and in kind are used to translate certain expressions that are suitable with such kinds of strategies.

4. Strategies are the best utilized to deal with these kinds of texts because they legal specific terms that are not easily translated unless using these strategies. 


\section{CONCLUSIONS}

In this paper, we can conclude the following:

Legal language is considered as the skillful use of words. Translation theory is obligatory since each one understands the other depending on a process formulated for the purpose above.

Since translation involves languages, the analysis and the description of translation process must draw up on a theory of translation. Moreover, written legal texts are featured with long sentences, complex structures, repetitions and an old archaic lexis. Most of the legal texts are translated depending on domestication since the legal-culture values are transformed using this kind of strategy.

Additionally, compensation in kind, splitting, merging, and by addition are also used to resort to the TT with the same effect explored in the ST. Addition is utilized to add certain words and expressions to cope with the TT. Elaboration and approximation is also used to give a balance between the texts, ST and TT.

\section{REFERENCES}

As- Safi, A.B. (trans) (2011). Taha Husain. The call of the Curlew. Leiden: E.J.Bril.

Baker, M. (2005). Routledge Encyclopedia of Translation Studies. London: Routledge.

Bassnett-McGuire, S. (1980). Translation Studies. London: Methuen.

Bell, R. T. (1991). Translation and Translaling: Theory and Practice. London and New York: Longman.

Catford, J. (1965). A Linguistic Theory of Translation. London:

Oxford University Press Curlew. Leiden: E.J.Bril. Evaluation of Theories of Translation". In R.W. Brislin .(ed). Translation: Applications and Research. New York: Gardner

Jaaskelainen, R. (1999). Tapping the process: An Explorative Study of Cognitive and Effective Factors Involved in Translating. Joensu: University of Joensuu Publications in Humanities.)

Kelly, L.G. (1979) .The True Interpreter. A History of translation Theory and Practice in the West. Oxford: London.

Loescher, W. (1991). Translation performance, translation process and and Translation Strategies. A Psycholinguistic Investigation. Tübingen, Gunter Narr, 1991, 307

Newmark, Peter.1981. Approaches to Translation. Oxford: Pergamon Press. Nida, E and Taber, C. (1969). The Theory and Practice of Translation. Leiden: E.J. Brill.

Nida, E.1976. A Framework for the Analysis and Evaluation of Theories of Translation". New York: Gardner Press, pp. 47-79.

Shaheen, M. (1991). Theories of translation and their applications to the teaching of English/Arabic-Arabic/English translating. (Ph.D. dissertation) Tuebingen: Guten Narr. 